\title{
Incubation Study of Cadmium with and without FYM at Various Day Intervals
}

\author{
V. N. Patel, K. V. Chaudhary*, B. H. Chaudhari and N. B. Gohil \\ Department of Soil Science and Agricultural Chemistry, Anand Agricultural University, \\ Anand- 388 110, Gujarat, India \\ *Corresponding author
}

A B S T R A C T

\begin{tabular}{|c|c|}
\hline $\begin{array}{l}\text { Ke y w o r d s } \\
\text { Cadmium, FYM, } \\
\text { Days, DTPA-Cd, } \\
\text { Incubation }\end{array}$ & $\begin{array}{l}\text { Incubation experiment was carried out to study the effect of cadmium }(\mathrm{Cd}) \text { and farm yard } \\
\text { manure (FYM) on DTPA- Cdat } 0,7,14,21,28,35 \text { and } 42 \text { days after incubation to know } \\
\text { DTPA extractable Cd of soil. At Department of Agricultural Chemistry and Soil Science, } \\
\text { BACA, AAU, Anand with five levels of Cd }\left(0,10,20,40 \text { and } 80 \mathrm{mg} \mathrm{kg}^{-1}\right) \text { and two levels }\end{array}$ \\
\hline Article Info & in a CRD (factorial) with three replications. In incubation study, DTPA- cadmium was \\
\hline $\begin{array}{l}\text { Accepted: } \\
\text { 22 May } 2018 \\
\text { Available Online: } \\
\text { 10 June } 2018\end{array}$ & $\begin{array}{l}\text { reduced at each level of cadmium with advanced in incubation period. The maximum } \\
\text { reduction in DTPA-cadmium content was observed in highest level of cadmium at } 42^{\text {nd }} \\
\text { day over } 0 \text { day. The FYM application @ } 1 \% \text { showed fixation of cadmium over no FYM } \\
\text { application. }\end{array}$ \\
\hline
\end{tabular}

\section{Introduction}

Increased world population along with modern industrialization and urbanization had ledcontinuous disposal of sewage and industrial wastes coupled with heavy use of phosphatic fertilizers leads to accumulation of heavy metal, especially cadmium in soils. Unfortunately, sludges, along with nutrients, also contain appreciable amount of heavy metals that persist in surface soils long after application so that soil gets contaminated with pollutant heavy metals. The increasing levels of cadmium in agriculture soils pose potential cadmium toxicity to plants, animals and human population (Tiller, 1986; Alloway,
1995). The cadmium as non-essential element is taken up through the roots of many species and accumulated in all plant parts including root, shoot, fruit and grain (Page et al., 1981). Taken up in excess, cadmium becomes poisonous and can cause serious health hazards to most living organisms (Jackson and Alloway, 1992).

Accumulation of $\mathrm{Cd}$ in human body causes several diseases like pain in bones with pathological fracture, wadding gaits, aminoaciduria, Osteomalacia, hyper-tension, liver cancer, pulmonary disease and emphysema. In Japan itaiitai disease in human was reported due to $\mathrm{Cd}$ toxicity. 
In India Cd toxicity has also been reported from rice growing areas and other agricultural lands nearby industrial estates. Gujarat is one of the most industrialized states in the country. The contribution of hazardous waste in Baroda, Ahmedabad, Valsad, Surat and Bharuch have been calculated to be about $38 \%, 22 \%, 17 \%, 12 \%$ and $11 \%$ respectively (Saxena and Vankatesan, 1995).

Metals in contaminated soils are present as chemical forms with different mobility and availability to human and ecological receptors. Consequently, there has been great concern for in-situ remedial strategies that render metals less mobile to minimize the environmental and human risks therefore it is advantageous to develop cost effective remediation strategies. FYM is the source of primary, secondary and micronutrient to the plant growth. It is a constant source of energy for hetrotropic microorganisms, help in increasing the availability of nutrient quality and quality of crop produce. Farm yard manure (FYM) improves the crop production (Kaihura et al., 1999) as well as improves soil physical properties (Chen et al., 1996) and can be used to reduce heavy metal hazards in plants (Yassen et al., 2007). Organic matter with respective groups such as hydroxyl, phenolic and carboxyl effectively controls the adsorption and complexation of heavy metal and the activity of metal in the soil (Lee $e t a l$., 2004; Mahmood, 2010).

\section{Materials and Methods}

Incubation experiment was carried out to study the effect of cadmium $(\mathrm{Cd})$ and farm yard manure (FYM) on DTPA- Cdat $0,7,14$, $21,28,35$ and 42 days after incubation to know DTPA extractable $\mathrm{Cd}$ of soil. At Department of Agricultural Chemistry and Soil Science, BACA, AAU, Anand with five levels of $\mathrm{Cd}\left(0,10,20,40\right.$ and $\left.80 \mathrm{mg} \mathrm{kg}^{-1}\right)$ and two levels of FYM (0 and $1 \%$ ) on loamy sand
(Typic Ustrochrepts) soil. The experiment was laid out in a CRD (factorial) with three replications.

To study the effect of FYM and incubation days on release pattern of $\mathrm{Cd}$ and its availability in absence of plant, a laboratory incubation study was conducted. Different levels of $\mathrm{Cd}$ were incubated in soil to maintain moisture at $50 \% \mathrm{WHC}$ to determine stabilization rate.Sample was taken from each 30 plastic cups at interval of $0,7,14,21,28$, 35, 42 Days. These samples were analyzed for DTPA-Cd extraction. Sampling method was nondestructive.

\section{Results and Discussion}

\section{Effect of incubation period}

The gradual decreasing trend was found in terms of incubation periods. As incubation periods increasing available $\mathrm{Cd}$ content was significantly decreasing in soil (Table 1). The lowest availability of $\mathrm{Cd}\left(23.78 \mathrm{mg} \mathrm{kg}^{-1}\right)$ was noted at the end of the incubation periods (Day 42) and highest availability of Cd was noted at 0 day $\left(27.56 \mathrm{mg} \mathrm{kg}^{-1}\right)$. The percentof $\mathrm{Cd}$ decreasing was 13.71 per cent from Day 0 to Day 42 respectively.

\section{Effect of FYM}

Application of FYM significantly decreased the availability of $\mathrm{Cd}$ in the soil (Table 1). The decrease in the availability of $\mathrm{Cd}$ (5.04 per cent over control) was obtained under $F_{1}$ level $\left(20 \mathrm{t} \mathrm{ha}^{-1}\right)$ of FYM application. The lowest availability of $\mathrm{Cd}(24.85 \mathrm{ppm})$ was noted at the application of FYM @ $20 \mathrm{t} \mathrm{ha}^{-1}$ and highest availability of $\mathrm{Cd}(26.17 \mathrm{ppm})$ was noted in no application of FYM.

Jones and Johnson (1989) documented that manure application affect the soil organic matter content, which may retain $\mathrm{Cd}$ in the 
soil against leaching and crop uptake. Eriksson (1990) reported that increasing the sorption capacity of the soil by adding organic matter, as peat would tend to decrease the amount of available $\mathrm{Cd}$ in the soil solution. Sarkunan et al., (1991) observed the decrease DTPA-extractable $\mathrm{Cd}$ in the soil due to addition of compost.

\section{Effect of cadmium}

With increasing rates of $\mathrm{Cd}$ application, there was a corresponding significant increase in the available Cd content of soil (Table 1). There was maximum available Cd content $(69.37 \mathrm{mg}$ $\mathrm{kg}^{-1}$ ) was found under $80 \mathrm{mg} \mathrm{kg}^{-1}$ level and minimum available $\mathrm{Cd}$ content $\left(0.04 \mathrm{mg} \mathrm{kg}^{-1}\right)$ was found under $0 \mathrm{mg} \mathrm{kg}^{-1}$ level. The findings were agreement with (Sarkunan et al., 1991).

\section{Interaction effect}

The $\mathrm{D} \times \mathrm{F}, \mathrm{D} \times \mathrm{Cdand} \mathrm{F} \times \mathrm{Cd}$ interactions for incubation study (Table 2, 3 and 4) were found to be significant.

\section{Effect of D X F interaction}

Combined effect of incubation days and FYM on the availability of $\mathrm{Cd}$ in the soil was given in the Table 2. Application of FYM @ $20 \mathrm{tha}$ ${ }^{1}$ reduced the availability of $\mathrm{Cd}$ in soil. With increasing incubation days there was decreasing available-Cd content was found significantly at all $\mathrm{Cd}$ levels except day-o which was at par with day-7 in respect to available-Cd content.

Table.1 DTPA-Cd ( $\left.\mathrm{mg} \mathrm{kg}^{-1}\right)$ as affected by levels of cadmium (Cd), FYM (F) and incubation period (D)

\begin{tabular}{|c|c|c|c|}
\hline Treatments & Cd content ( $\left.\mathrm{mg} \mathrm{kg}^{-1}\right)$ & Treatments & Cd content ( $\left.\mathrm{mg} \mathrm{kg}^{-1}\right)$ \\
\hline \multicolumn{2}{|c|}{ Days after incubation (D) } & \multicolumn{2}{|c|}{ Levels of FYM $(\mathrm{F})$} \\
\hline Day-0 & 27.56 & $\mathrm{~F}_{0}: 0 \% \mathrm{FYM}$ & 26.17 \\
\hline Day-7 & 26.81 & $\mathrm{~F}_{1}: 1 \% \mathrm{FYM}$ & 24.85 \\
\hline Day-14 & 26.39 & SEm \pm & 0.06 \\
\hline Day-21 & 25.26 & $\mathrm{CD}(\mathrm{P}=\mathbf{0 . 0 5})$ & 0.17 \\
\hline Day-28 & 24.75 & \multicolumn{2}{|c|}{ Levels of cadmium $(\mathbf{C d})$} \\
\hline Day-35 & 24.04 & $\mathrm{Cd}_{0}: 0 \mathrm{mg} \mathrm{kg}^{-1}$ & 0.04 \\
\hline Day-42 & 23.78 & $\mathrm{Cd}_{10}: 10 \mathrm{mg} \mathrm{kg}^{-1}$ & 7.31 \\
\hline SEm \pm & 0.11 & $\mathrm{Cd}_{20}: 20 \mathrm{mg} \mathrm{kg}^{-1}$ & 16.40 \\
\hline \multirow[t]{4}{*}{$\mathrm{CD}(\mathrm{P}=0.05)$} & 0.31 & $\mathrm{Cd}_{0}: 40 \mathrm{mg} \mathrm{kg}^{-1}$ & 34.44 \\
\hline & & $\mathrm{Cd} 8_{0}: 80 \mathrm{mg} \mathrm{kg}^{-1}$ & 69.37 \\
\hline & & SEm \pm & 0.09 \\
\hline & & $\mathrm{CD}(\mathrm{P}=\mathbf{0 . 0 5})$ & 0.26 \\
\hline \multicolumn{2}{|c|}{$\begin{array}{l}\text { Significant } \\
\text { Interactions }\end{array}$} & \multicolumn{2}{|c|}{$\begin{array}{c}\mathbf{D} \times \mathbf{F} \\
\mathbf{D} \times \mathbf{C d} \\
\mathbf{F} \times \mathbf{C d}\end{array}$} \\
\hline \multicolumn{2}{|c|}{$\mathrm{CV} \%$} & \multicolumn{2}{|c|}{2.37} \\
\hline
\end{tabular}


Table.2 Interaction effect of days and FYM $(\mathrm{D} \times \mathrm{F})$ on $\mathrm{Cd}\left(\mathrm{mg} \mathrm{kg}^{-1}\right)$ status in soil

\begin{tabular}{|c|c|c|c|c|c|c|c|}
\hline D X F & Day-0 & Day-7 & Day-14 & Day-21 & Day-28 & Day-35 & Day-42 \\
\hline$F_{0}$ & 27.84 & 27.24 & 26.86 & 25.93 & 25.56 & 24.89 & 24.08 \\
\hline$F_{1}$ & 27.28 & 26.38 & 25.92 & 24.58 & 23.94 & 23.18 & 22.67 \\
\hline \multicolumn{5}{r}{ SEm+ $\mathbf{0 . 1 6}$} \\
\hline
\end{tabular}

Table.3 Interaction effect of days and cadmium $(\mathrm{D} \times \mathrm{Cd})$ on $\mathrm{Cd}\left(\mathrm{mg} \mathrm{kg}^{-1}\right)$ status in soil

\begin{tabular}{|c|c|c|c|c|c|c|c|}
\hline D X Cd & Day-0 & Day-7 & Day-14 & Day-21 & Day-28 & Day-35 & Day-42 \\
\hline $\mathbf{C d}_{0}$ & 0.03 & 0.02 & 0.03 & 0.03 & 0.03 & 0.02 & 0.02 \\
\hline $\mathrm{Cd}_{10}$ & 8.59 & 8.18 & 7.83 & 7.29 & 6.96 & 6.26 & 6.05 \\
\hline $\mathrm{Cd}_{20}$ & 18.38 & 17.81 & 17.43 & 16.38 & 15.62 & 14.72 & 14.49 \\
\hline $\mathrm{Cd}_{40}$ & 36.92 & 35.64 & 35.22 & 34.20 & 34.05 & 32.67 & 32.35 \\
\hline $\mathrm{Cd}_{80}$ & 73.88 & 72.34 & 71.44 & 68.39 & 67.08 & 66.51 & 65.96 \\
\hline
\end{tabular}

Table.4 Interaction effect of FYM and cadmium $(\mathrm{F} \times \mathrm{Cd})$ on $\mathrm{Cd}\left(\mathrm{mg} \mathrm{kg}^{-1}\right)$ status in soil

\begin{tabular}{|c|c|c|}
\hline F X Cd & $\mathrm{F}_{0}$ & $F_{1}$ \\
\hline $\mathrm{Cd}_{\mathbf{0}}$ & 0.04 & 0.03 \\
\hline $\mathrm{Cd}_{10}$ & 7.58 & 7.03 \\
\hline $\mathbf{C d}_{20}$ & 17.14 & 15.67 \\
\hline $\mathrm{Cd}_{40}$ & 35.40 & 33.59 \\
\hline $\mathbf{C d}_{80}$ & 70.81 & 67.92 \\
\hline & $\mathrm{SEm}+0.13$ & $\mathrm{CD}(\mathrm{P}=0.05) \quad 0.37$ \\
\hline
\end{tabular}

\section{Effect of D X Cd interaction}

Combined effect of incubation days and $\mathrm{Cd}$ on the availability of $\mathrm{Cd}$ in the soil was given in the Table 3. Data pertaining to available$\mathrm{Cd}$ content in soil as influenced by $\mathrm{D} \times \mathrm{Cd}$ interaction showed that increasing trend in available- $\mathrm{Cd}$ content was found in soil with the increasing levels of $\mathrm{Cd}$ but with increasing incubation days, there was decreasing available-Cd content found significantly at all Cd levels.

The highest Available $\mathrm{Cd}$ found at 0 day and lowest available-Cd was found at day-42 in each $\mathrm{Cd}$ levels. Available-Cd0, Cd10 and $\mathrm{Cd} 20$ ppm was at par with day-7.

\section{Effect of F X Cd interaction}

Combined effect of $\mathrm{Cd}$ and FYM on the availability of $\mathrm{Cd}$ in the soil was given in the Table 4. Application of FYM @ $20 \mathrm{t} \mathrm{ha}^{-1}$ reduced the availability of $\mathrm{Cd}$ in soil. This might be due to presence of carboxyl, hydroxyl and phenoxy group in FYM chelate the applied $\mathrm{Cd}$ in soil which ultimately decreased its availability.

In conclusion, the results of incubation study, the application of FYM and days of incubation reduced the DTPA-Cd content in soil, while with increase in $\mathrm{Cd}$ level increase the DTPA-Cd in incubation study. 
The FYM application @ $20 \mathrm{t} \mathrm{ha}^{-1}$ showed fixation of cadmium to the extent of 4.3 per cent under $\mathrm{Cd}_{80}$ over no FYM application.

\section{Acknowledgement}

I owe my profoundest sense of gratitude and sincere thanks to faculty teachers Dr. R. B. Patel (Professor and Head), Dr. K. C. Patel (Associate professor), Dr V. P. Ramani (Associate research scientist), Dr. A. S. Bhanvadia (Associate professor) and Dr G. J. Mistry(Associate professor) for their helping mentality and words of inspiration.

\section{References}

Alloway, B. J. (1995). Heavy Metals in Soils, 2nd ed. Blackie Academic and Professional Publishers, London. Pp: 368.

Chen, H.M., Zheng, C.R., Tu, C., and Shen, Z. G., (1996).Chemical methods and phytoremediation of soil contaminated with heavy metals. Chemosphere, 41: 229-234.

Erikson, J. (1990). Factors influencing adsorption and plant uptake of $\mathrm{Cd}$ from agricultural soils. Swedish University of Agricultural Sciences Uppsala, Sweden, Pp. 28.

Jackson A. P. and Alloway B. J. (1992). The transfer of cadmium from agricultural soils to the human food chain. In Biogeochemistry of Trace Metals. Ed. D C Adriano. Pp. 109-158.

Jones K.C and Johnston A.E (1989), Cd in cereal grain and herbage from long-term experimental plots at Rothamsted, U.K. environmental pollution57: 199-216.

Kaihura, B.S., Kullaya, I. K., Kilasara, M., Aune, J.B., Singh, B.R., Lal, R. (1999). Soil quality effects of accelerated erosion and management systems in three eco-regions of Tanzania. Soil Tillage Research, 53: 59-70.

Lee, T. M., Lai, H. Y. and Chen, Z. S. (2004). Effect of chemical amendments on the concentration of $\mathrm{Cd}$ and $\mathrm{Pb}$ in long term contaminated soil. Chemosphere. 57: 1459-1471.

Mahmood, M. (2010). Phytoextraction of heavy metal-the process and scope for remediation of contaminated soils. Soil Environment, 29: 91-109.

Page, A. L., Bingham, F. T. and Chang, A. C. (1981). Effect of heavy metal pollution on plant, N. W. Applied Science, London.

Sarkunan V., Misra, A. K. and Nayyar, P. K. (1991). Effect of compost, lime and P on cadmium toxicity in rice. Journal of Indian Society of Soil Science, 39(3): 595-597.

Saxena, A. K. and Venkatesan, N. (1995). Hazardous waste generation in Gujarat. Productivity. 36(1):165-168.

Tiller, K.G.(1986). Trans. $13^{\text {th }}$ Int. Conger. Soil Sci.1: 29.

Yassen, A. A., Nadia, B. M, and Zaghloul, M. S. (2007). Role of some organic residues as tools for reducing heavy metals hazards in plant. World Journal of Agriculture Science,3(2): 204-207.

\section{How to cite this article:}

Patel, V. N., K. V. Chaudhary, B. H. Chaudhari and Gohil, N. B. 2018. Incubation Study of Cadmium with and without FYM at Various Day Intervals. Int.J.Curr.Microbiol.App.Sci. 7(06): 3340-3344. doi: https://doi.org/10.20546/ijcmas.2018.706.391 